\title{
REVOLUTION IN MILITARY AFFAIRS AND OUTER SPACE
}

\author{
Jakub FUČÍK \\ Centre for Security and Military Strategic Studies, University of Defence, Brno, \\ The Czech Republic \\ jakub.fucik@unob.cz
}

\begin{abstract}
Concept of the Revolution in Military Affairs (RMA) analyses and describes processes of major changes in military-strategic dimension, which provide possibilities especially for states to enhance their military power and establish superiority over their opponents. Contemporary, development of new (weapon) technologies (e.g. precision-guided munitions, unmanned aerial vehicles) and doctrines (e.g. network centric warfare, system-of-systems) represents such opportunity. Outer space in this context represents relatively new dimension of warfare with increasing importance for strategical thinking of all main state actors (e.g. China, Russia, and the U.S.). This paper deals with relation between RMA and outer space. The aim of this paper is to analyses how outer space and space technologies influence contemporary/future RMA and vice versa.
\end{abstract}

Keywords: C4I, Network Centric Warfare, Outer Space, Revolution in Military Affairs.

\section{Introduction}

Since 1980s, it is possible to identify changes in military-strategic dimension, which are associated with concept of the Revolution in Military Affairs (RMA). Development of new (weapon) technologies (e.g. precision-guided munitions, unmanned aerial vehicles) and doctrines (e.g. network centric warfare, system-of-systems) represents opportunity (and challenges) especially for states to enhance their military power [1]. In this context, the importance of the fourth dimension of warfare - outer space - is increasing which could be also demonstrated on the approach of all main state actors (e.g. China, Russia, and the U.S.) and their space policies.

Aim of this paper is focused on examination of the relationship between the RMA and the outer space. The main goal is to identify how (in what form) these concepts affect mutually, i.e. how one of them shapes character of the other one. This distinction is based on hypothesis that between the current RMA and outer space is interdependent relationship, which can be analyzed in two dimensions: 1) how the current RMA is influenced by outer space; 2) how the current RMA affects outer space.

RMA for the purpose of this paper is defined as the process and condition of revolutionary changes in the nature or method of warfare based on the external manifestations (actions) which use the threat of force or the use of force to achieve political aims [2]. The "revolutionary" then refers to the radical nature of these changes, when in relation to the original system and its elements must occur abruptly de facto preserving just a minimum similarity (e.g. in features, by which the system is identified). We cannot therefore speak of a progressive (gradual) transition and the establishment of new elements into the existing framework and its evolutionary transition. With regard to the military dimension of this revolution, we can use the modified characteristics defined by Jeffrey R. Cooper, which talks about: "... non- 
follow and unprecedented change process military capabilities, resulting in transformation efficiency of combat operations" [3].

However, this paper does not focus on RMA in aforementioned "general" form, but on its expression through specific processes or changes. This is labeled by period of about the 80s of the last century and continuing today. Relevant changes in the method of warfare are founded on a technological level in the introduction and use of advanced weapons and information systems (e.g. precision-guided munitions PGM, unmanned aircraft, and remote sensing devices/sensors).

Changes on the doctrinal dimension are represented by the establishment of the concepts of so-called System of Systems (SoS) and Network Centric Warfare (NCW). The first mentioned is based on two fundamental elements - information and integration (cooperation). The prerequisite is an amalgamation of particular systems and components, such as command, control, computers, communications and information (C4I), into one coherent functional framework [4]. The aim is to provide situational awareness on the battlefield essentially in real time for all relevant components of the armed forces.

The second concept is associated with the very existence and use of functional links among the units on the battlefield, which are integrated into the aforementioned framework. Their interdependence allows to maximize their combat skills and on the other hand, to compensate for weaknesses (e.g. through an almost perfect fire support, information about intentions of the enemy). Full use of this potential is connected e.g. to implementation of so-called "swarming" tactic, which in itself implies synchronized and highly flexible combat deployment of a large number of small clusters (military units) [5].

In practical terms, the army, which fully applies both concepts, is allowed to accurately interfere (invade) the opponent at his most vulnerable areas, to prevent his possible attempts to initiate counterattacks or enact countermeasures and therefore completely take over combat initiative and paralyze his opponent.

The outer space is in this paper understood in geopolitical terms. Through the "traditional" considerations of environmental influences on the interaction of various actors that include land, maritime and aerospace dimension (e.g. works of $\mathrm{H}$. Mackinder, A. T. Mahan or spouses Sprouts) extended to an additional dimension that exceeds (bridges) system related "only" to one planet. By its nature, it is airless space that surrounds celestial bodies (planets, stars, asteroids etc.) [6]. Interest and consideration of this space in the human history is dating back to its relatively depth. Leaving aside any explanation of the possible purpose of megalithic structures e.g. In the English Stonehenge, we can point among others on the theory of Indian astronomer and mathematician Aryabhata about the year 500 A.D., which treats the Earth as a sphere rotating around its axis and at the same time along with the other planets orbiting the Sun [7].

A fundamental shift in space exploration has brought the second half of the last century. Plotting the first artificial satellite to orbit the Earth, which was followed by manned missions and landing on the lunar surface, not only meant a practical confirmation of the accessibility of this dimension, but also opened up a completely new set of ways of its utilization.

In general, these options can be divided into two groups - civilian and military. The dividing criterion is the nature of the activities or artificial bodies (satellites, stations, etc.), which are operated or located in this environment. Civilian group includes e.g. the establishment and use of satellite networks for monitoring weather or television signal transmission. Military group includes e.g. spy satellite network, 
satellite navigation of the combat troops or weapons platform designed for interception of ballistic missiles. In accordance with the aforementioned definition, we also cannot forget to anti-satellite weapons (ASAT). Although they can be placed on the Earth's surface (the example of the U.S., Russia, China), but their use is directly situated into space. At the same time, it is necessary to state that the boundary between these two categories is quite unclear, or these two groups often overlap in their elements, and distinguishing them in practice is rather problematic.

We can define such a phenomenon as socalled "dual-use" technologies or activities. Satellite navigation network, for example, can be used not only to determine the position of civilian actors, but also to coordinate the advancement of combat groups or homing guided missiles or drones (a reference e.g. to the American GPS system). Similarly, the Soviet space stations Salyut class were used for both civil and military purposes [8].

Security or economical aspects however do not generally represent the sole motivation for the individual states to obtain and enhance their space capabilities. For example, element of (gaining) prestige can be identified as one of the indicators of the position in the international system in terms of power. The leading states in this regard must act as bearers of technological progress. The ownership and the development of technologies for activities in the outer space are fulfilling this characteristic completely. Other motives can include influence of strategic culture, significance of the military-industrial complex or personality of the leaders of relevant country [9].

\section{Impact of outer space on RMA}

From the geopolitical point of view, outer space represents next dimension for the projection of (state) power, which is related not only to the opportunity for cooperation of individual actors in the exploration and exploitation, but also to the emergence of competition, eventually conflict situations, while achieving their own interests. The historical example is the so-called "Space Race" between the U.S. and USSR about the second half of the last century. Its climax is universally known - on 20th July 1969 American crew of the spaceship Apollo 11 successfully achieved lunar surface [10]. Astronauts Neil Armstrong and Edwin "Buzz" Aldrin became the first people who reached other planet (celestial body).

The military dimension of the conflict generally followed the context of the Cold War and was evident in both of these countries through their research and development activities. Since the 60 s of the last century we can identify development of the Soviet projects for the acquisition of bombardment (FOBS/R-36), missile defense (Kaskad, Skif) and anti-satellite (IS， IS-MU， IS-MD/Naryad, Naryad-V) systems placed in the space [11]. Strategic Defense Initiative (SDI) can represent example of the U.S. projects. The goal of this research program was to build a multilevel system of missile defense that would allow the destruction of the opponent's missiles in all phases of flight. The program envisaged the placement of some elements of defense (e.g. laser weapons or kinetic interceptors) right into the space [12]. Simultaneously, the modified weapon platforms could be able to fulfil the role of ASAT. However, with the end of the Cold War the individual projects were phased out or transformed [13].

On the other hand, the development of space technologies in this sense provide a real basis for the vision of the current RMA. The building of robust satellite network may provide to individual states unprecedented awareness, monitoring, navigation and communication capabilities. These (sensor) elements are crucial for the implementation of the concepts associated with the current RMA. Both SoS and NCW share especially (increased) requirements 
for information accuracy (in real time), multi-level communication network among combat units and their headquarters. Satellite technology provide opportunity to minimization of "fog of war". The result is an overall awareness of the movement and distribution of the opponent's forces in real time.

Similarly, satellite technology provides a much-desired feature of precision-guided munitions, i.e. the real accuracy [14]. Operations Steel Rain and Desert Storm which are connected with, in principle, the rapid destruction of armed resistance from the Iraqi army, despite some former (sceptical) predictions about the expected length and possible casualties on the coalition side, represent examples of direct manifestation how space technologies influenced warfare in the terms of RMA.

\section{Impact of RMA on the outer space}

Aforementioned example from the Cold War highlighted the successful identification of potential strategic importance of outer space (with all its implications) for the power of individual states and their position. This finding is further supported by the development of space policies of other major actors in the international system (China, France, India, Iran, Israel, Japan, the United Kingdom and others.). Similarly, e.g. competition for primacy in achieving Mars by manned spaceflight is sometimes referred to as "the new space race" and new source of clash among participated parties (actors).

Contribution of the outer space can be initially seen in its location and actual size (or infinity). Space represents the domain in which they are a part of Earth other planets, stars and celestial bodies. However, currently from a security standpoint is for various actors in the international environment not (so) important that this area has to be overcome to achieve other celestial bodies.

Given the attainability of the general level of technological development of mankind, which would enable both short and economic spaceflights among the planets, and also the pursuit of a permanent settlement e.g. for the purpose of mining and quarrying, we will not likely witness to conflicts comparable (with a certain degree of analogy) to fight for control of the shipping routes, respectively overseas colonies, in the near future.

On the other hand, the beginnings of the aforementioned the U.S. - Soviet rivalry pointed that individual states "recognize" another implication of this characteristic. Any position on the surface of Earth is directly accessible from its orbit, irrespective of uneven terrain, altitude and its distance (not only from the rest "civilization", but also from the mainland itself). Disposing relevant capacities in space, therefore, plays a relatively major role in the ability of individual actors to project their power, or military power, on a global scale. This issue highlights among others the U.S. National Space Security Strategy from 2011 [15].

Representatives of China, Russia and the United States, i.e. the leading countries that focus on the development of military programs and projects applying theses current RMA, agree that outer space plays a key role in the establishment of military capabilities and infrastructure [14]. For example, unmanned aerial vehicles (UAV) require for achieving their effective combat results comprehensive system of communication, navigation and monitoring satellites [16].

Protection of corresponding systems is becoming for the state one of its key security interest to ensure that aforementioned capabilities (PGMs, UAVs etc.) can be used according their purpose. From this point of view, establishing concepts of the current RMA is deeply connected to militarization of this domain, which highlight not only further increase in its strategic value, but also issues of "dual-use" technologies. 


\section{Conclusions}

Paper was focused on examination of the relationship between the current RMA and the outer space. This interdependent relationship was analysed in two dimensions: 1) how the current RMA is influenced by outer space; 2) how the current RMA affects outer space.

In the first dimension, we can identify the importance of development of space technologies for operability of the modern weapon systems (for example UAVs or PGMs). Robust satellite network provide unprecedented awareness, monitoring, navigation and communication capabilities. These elements are also crucial for the implementation of the concepts of SoS and NCW.

The second dimension is highlighted by strategic value of the outer space.
Nowadays, we should especially mentioned that any position on the surface of Earth is directly accessible from its orbit, irrespective of uneven terrain, altitude and its distance. Space systems, which are dedicated to ensure increasing of military effectiveness in the terms of the current RMA, also represent some kind of vulnerability (e.g. threat of enemy ASATs). From this point of view, establishing concepts of the current RMA is deeply connected to securitization and militarization of this domain.

\section{Acknowledgements}

The work presented in this paper has been supported by the Ministry of Defence of the Czech Republic (Research Project “STRATAL” No. 907930101023).

[1] Jakub FUČÍK and Zdeněk KŘÍŽ, Informační revoluce, vojensko-technická revoluce, nebo revoluce ve vojenských záležitostech? (Information Revolution, MilitaryTechnical Revolution, or Revolution in Military Affairs?), Obrana a strategie, Vol. 13, No. 2, 2013, pp. 15-24.

[2] For further details see Colin S. GRAY, Strategy for Chaos - Revolution in Military Affairs and The Evidence of History, London, Frank Cass, 2005.

[3] Jeffrey R. COOPER. Another View of the Revolution in Military Affairs, http://www.strategicstudiesinstitute.army.mil/pdffiles/pub240.pdf, Strategic Studies Institute, 1994, p. 13.

[4] For further details see e.g. William A. OWENS and Ed OFFLEY. Lifting the Fog of War. New York, Farrar Straus Giroux, 2000.

[5] For more details see David S. ALBERTS, John J. GARTSKA and Frederick P. STEIN, Network Centric Warfare: Developing and Leveraging Information Superiority, Washington D.C., CCRP, 1999.

[6] Barry F. DAITON, Time and Space, Montreal, McGill-Queen's University Press, 2001, pp.132 - 133.

[7] Michael J. SHEEHAN, The International Politics of Space, New York, Routledge, 2007, p. 144.

[8] Curtis PEEBLES, Battle for Space, London, Book Club Associates, 1983, p. 29.

[9] For further details see Jakub FUČÍK, Tvorba vesmírné politiky aneb stejné motivy $u$ odlišných států? (Formulation of Space Policy, or the Same Motives at Different States?), Master Thesis, Faculty of Social Studies, Masaryk University, Brno, 2013.

[10] Charles A. MURRAY and Catherine B. COX, Apollo: The Race to the Moon, New York, Touchstone, 1990, p. 356. 
[11] Miroslav GYÜRÖSI, The Soviet Fractional Orbital Bombardment System Program, http://www.ausairpower.net/APA-Sov-FOBS-Program.html, Air Power Australia, 2010, updated 2012; and/or Anatoly ZAK, Russian military space program: Yesterday, today and tomorrow, http://swfound.org/media/53469/rsw_milspace_web.pdf, RussianSpaceWeb.com, 2011.

[12] For further details see Kevin CROWLEY, The Strategic Defense Initiative (SDI): Star Wars, http://www.coldwar.org/articles/80s/SDI-StarWars.asp, n.d.; and Petr SUCHÝ, Reagan a řiše zla. Vývoj americké zahranični politiky a vztahů mezi supervelmocemi $v$ letech 1981 - 1989 (Reagan and the Evil Empire. The development of US foreign policy and relations between the superpowers in the years 1981 - 1989), Brno, CDK, 2004, pp. $97-106$.

[13] Matthew MOWTHORPE, The United States Requirements for an Antisatellite (ASAT) Capability, The Journal of Social, Political and Economic Studies, Vol. 27, No. 2, pp. $132-147,2002$.

[14] Compare with Michael NEARY, Space: The Next Revolution in Military Affairs?, Journal of International Service, Vol. 18, No. 1, 2008, p. 114.

[15] U.S. National Space Security Strategy, https://www.hsdl.org/?view\&did=10828, 2011.

[16] For further details about UAVs see for example Richard STOJAR, Bezpilotní prostředky a problematika jejich nasazení v soudobých konfliktech (The Unmanned Aerial Vehicles and Issues Connected with Their Use in Contemporary Conflicts), Obrana a strategie, Vol. 16, No. 2, 2016, pp. 5-18. 